\title{
Past, Present, and Future of Texas Industrial Minerals
}

\author{
J. Richard Kyle ${ }^{1}$ (D) Brent A. Elliott ${ }^{1}$
}

Received: 5 October 2018 / Accepted: 14 January 2019 /Published online: 28 February 2019

(C) The Author(s) 2019

\begin{abstract}
Texas is a major producer of industrial mineral resources required by the state's ever-growing population that now exceeds 28 million. Texas typically ranks in the top three states for the value of non-fuel mineral production with a total value of $\$ 5.2$ billion in 2017, accounting for $6.9 \%$ of the total US mineral value. Almost $90 \%$ of current Texas industrial mineral value comes from the production of cement, crushed stone, industrial sand, and construction sand and gravel. Construction material consumption is focused in the 25 metropolitan areas of the state with populations of $>100,000$ residents. Industrial mineral consumption is dominated by the four most populous regions of the state-Houston, Dallas-Fort Worth, San Antonio-New Braunfels, and Austin-Round Rock - with an aggregate population of more than 18 million. More than 11,000 employees work in Texas mining and processing operations. Texas produces more crushed stone than any other state from more than 200 quarries; a similar number of operations produce sand and gravel. Specialty industrial sand production for use as proppants in hydraulic fracturing for enhanced petroleum production serves as an excellent example of how developments in one industry sector can markedly affect another industry; the production of industrial sand in Texas has markedly increased over the past decade, reaching $\$ 1.3$ billion in 2014. With Texas' population projected to reach 50 million by 2050 , continuing in-state development and production of industrial minerals will be required to supply its residential, commercial, and industrial users. Favorable geology and economic factors provide opportunities for identification and development of new industrial mineral production sites.
\end{abstract}

Keywords Industrial minerals · Construction materials · Chemical materials · Industrial sand · Geology · Exploration and development

\section{Introduction}

As many industrial rocks and minerals are relatively common Earth materials, low-cost surface extraction and processing techniques typically are required for commercial viability. Thus, industrial mineral production sites usually occur where suitable geologic sources occur at or near the surface near the population centers that will consume the industrial minerals, and/or where an efficient transportation network is available to deliver these products to regional, national, or global markets.

Texas typically ranks in the top three US states for the value of non-fuel mineral production, accounting for $6.9 \%$ of the total US mineral value in 2017 [1]. As Texas lacks significant metals production, this value represents industrial mineral

J. Richard Kyle

rkyle@jsg.utexas.edu

1 Bureau of Economic Geology, Jackson School of Geosciences, University of Texas at Austin, University Station, Box X, Austin, TX 78713-8924, USA production totaling $\$ 5.2$ billion (Fig. 1). The total value of industrial mineral production in Texas from 2000 to 2015 was almost $\$ 50$ billion (Table 1; Fig. 2) [3]. Additional value and related employment are provided by imported materials that are refined or processed for use in Texas industries. As locally produced industrial rocks and minerals are used extensively in the construction industry, the amount and value of their annual production typically provide a direct measure of the state's economic vitality. Industrial mineral consumption trends broadly track regional population and are reflected in the doubling of Texas' population since 1980 to its current 28 million residents (Fig. 1).

This study provides an overview of recent trends for Texas industrial mineral resources production and consumption, reviews the geologic framework that controls the distribution of these natural materials, and examines projected industrial mineral demands to 2050 and the potential for in-state extraction developments to supply these materials. The information reported here draws heavily on the references provided, with major sources of Texas mining and industrial information provided by the United States Geological Survey National Minerals Information Center [3], the Mine Safety and Health 


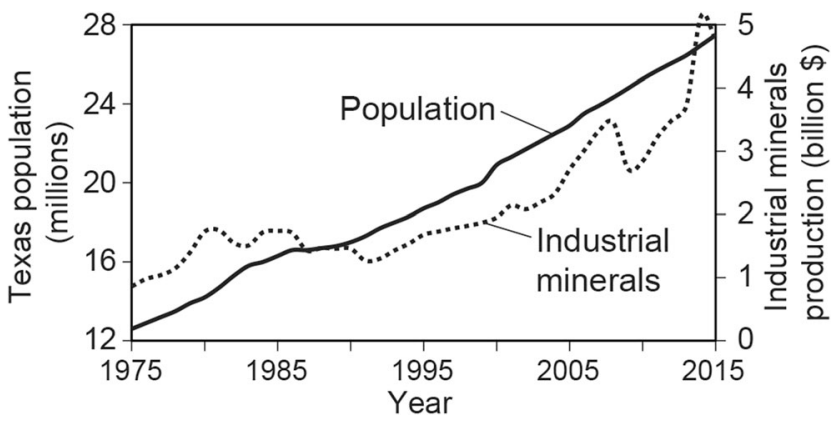

Fig. 1 Growth of Texas population and industrial mineral production from 1975 to 2015. Data compiled from the Texas Demographic Center [2] and the U.S. Geological Survey [3]

Administration [4], Texas Bureau of Economic Geology [5, 6], and the Texas Commission on Environmental Quality [7]. For in-depth geologic, market, and usage information on the diverse commodities discussed, the reader is referred to industrial rock and mineral compilations, e.g. [8], as well as annual summaries available from the USGS National Minerals Information Center [3].

\section{Texas Geography and Demographics}

Texas comprises a variety of physiographic provinces, extending from the coast and its barrier islands to the High Plains of the Texas Panhandle and basin-and-range topography of Trans-Pecos Texas (Fig. 3) [9]. Major river systems drain the continental interior and extend through (and their Cenozoic ancestors built) the Coastal Plain. Climate, and rainfall, varies from the subtropical conditions along portions of the coast to the semi-desert and mountainous terrains of the western part of the state. Agriculture activities are extensive in much of the state and depend on seasonal water supplies or subsurface water for irrigation. The $1200-\mathrm{km}$ (750-mi) international border with Mexico denotes opportunities and challenges for supply and consumption issues for all resources, e.g., the larger Juarez, Chihuahua, metropolitan center contiguous with El Paso. The coastal region has major ports and industrial facilities, particularly hydrocarbon refineries and petrochemical plants, facilitating access to international markets and egress for foreign material supplies.

Texas is divided into 254 counties, ranging in size from more than $16,000 \mathrm{~km}^{2}\left(6000 \mathrm{mi}^{2}\right)$ to less than $400 \mathrm{~km}^{2}(150$ $\left.\mathrm{mi}^{2}\right)$. Industrial rocks and minerals are produced in most large counties, commonly related to local construction and industrial activities, thus providing local employment. Uncommon mineral concentrations provide specialty products for regional, national, and international distribution. An important issue concerning industrial mineral resource development is land access in that more than $95 \%$ of Texas land is privately owned [10]. This situation provides opportunities, as well as

Table 1 Texas industrial minerals production from 2000 through 2015

\begin{tabular}{|c|c|c|c|c|c|c|c|c|c|c|c|c|c|c|c|c|c|c|}
\hline \multirow[b]{2}{*}{ Year } & \multicolumn{2}{|c|}{$\begin{array}{l}\text { Crushed } \\
\text { stone }\end{array}$} & \multicolumn{2}{|c|}{ Cement } & \multicolumn{2}{|c|}{$\begin{array}{l}\text { Sand and } \\
\text { gravel }\end{array}$} & \multicolumn{2}{|c|}{$\begin{array}{l}\text { Industrial } \\
\text { sand }\end{array}$} & \multicolumn{2}{|c|}{$\begin{array}{l}\text { Common } \\
\text { clay }\end{array}$} & \multicolumn{2}{|l|}{ Lime } & \multicolumn{2}{|l|}{ Salt } & \multicolumn{2}{|c|}{$\begin{array}{l}\text { Dimension } \\
\text { stone }\end{array}$} & \multirow{2}{*}{$\begin{array}{l}\text { *Other } \\
\text { M\$ }\end{array}$} & \multirow{2}{*}{$\begin{array}{l}\text { Total } \\
\text { M\$ }\end{array}$} \\
\hline & Mt & $\mathrm{M} \$$ & Mt & $\mathrm{M} \$$ & Mt & M\$ & $\mathrm{Mt}$ & M\$ & Mt & M\$ & Mt & $\mathrm{M} \$$ & $\mathrm{Mt}$ & M\$ & It & M\$ & & \\
\hline 000 & 12 & 496 & 9.5 & 712 & 80.8 & 408 & 1.8 & 45 & 2. & 9. & 1.6 & 105 & 10.8 & 104 & 0.08 & 11.5 & 59 & 195 \\
\hline 2001 & 126 & 606 & 10.7 & 778 & 82.9 & 405 & 1.5 & $\pi$ & 2.1 & 0.0 & 1.6 & 108 & 9.4 & 104 & 0.09 & 12.6 & 40 & 2140 \\
\hline 002 & 113 & 543 & 10.8 & 776 & 82.6 & 413 & 1.7 & 62 & 2.2 & 21.2 & 1.5 & 98 & 9.1 & 103 & 0.07 & 12.2 & 61 & 2090 \\
\hline 003 & 126 & 595 & 11.4 & 783 & 86.2 & 425 & 1.9 & 02 & 2.1 & 8.9 & 1.6 & 110 & 9.6 & 116 & 0.09 & 16.4 & 54 & 2190 \\
\hline 004 & 122 & 621 & 11.5 & 83 & 81.7 & 436 & 2.8 & 109 & 2.2 & 8.9 & 1.6 & 115 & 9.8 & 118 & 0.06 & 15.2 & 69 & 2330 \\
\hline 005 & 137 & 820 & 12.0 & 1000 & 80.7 & 472 & 2.8 & 114 & 2.3 & 8.7 & 1.6 & 112 & 9.6 & 118 & 0.04 & 12.2 & 54 & 2710 \\
\hline .006 & 141 & 861 & 11.7 & 1121 & 99.5 & 603 & 1.5 & 66 & 2.4 & 12.6 & 1.7 & 130 & 9.6 & 132 & 0.23 & 30.1 & 68 & 3320 \\
\hline 007 & 153 & 1020 & 11.3 & 1112 & 96.1 & 656 & 3.3 & 123 & 2.0 & 12.6 & 1.6 & 132 & 9.0 & 143 & 0.24 & 31.6 & 90 & 3320 \\
\hline 2008 & 150 & 1100 & 11.4 & 1150 & 88.3 & 631 & 3.6 & 139 & 2.1 & 13.7 & 1.5 & 128 & 9.1 & 157 & 0.27 & 27.7 & 103 & 3450 \\
\hline 2009 & 110 & 784 & 8.6 & 843 & 71.9 & 540 & 3.2 & 143 & 1.8 & 13.0 & 1.0 & 105 & 8.9 & 164 & 0.24 & 42.0 & 86 & 2720 \\
\hline 2010 & 114 & 805 & 9.1 & 812 & 71.5 & 540 & 4.5 & 202 & 1.7 & 14.0 & 1.3 & 136 & 9.1 & 173 & 0.20 & 57.0 & 101 & 2840 \\
\hline 2011 & 117 & 791 & 9.4 & 951 & 79.2 & 593 & 7.0 & 337 & 1.8 & 13.3 & 1.4 & 148 & 9.3 & 180 & 0.54 & 117.0 & 90 & 3220 \\
\hline 2012 & 134 & 1020 & 10.2 & 969 & 80.8 & 584 & 7.0 & 357 & 1.9 & 13.4 & 1.4 & 154 & 7.8 & 161 & 0.77 & 151.0 & 81 & 349 \\
\hline 2013 & 135 & 1080 & 10.3 & 1032 & 77.0 & 622 & 7.1 & 434 & 1.5 & 12.1 & 1.4 & 154 & 7.8 & 166 & 0.90 & 151.0 & 69 & 3720 \\
\hline 2014 & 154 & 1340 & 11.3 & 1213 & 76.0 & 671 & 16.5 & 1300 & 1.7 & 14.4 & 1.5 & 171 & 8.0 & 182 & 0.92 & 159.0 & 79 & 5130 \\
\hline 2015 & 162 & 1610 & 10.7 & 1200 & 83.7 & 790 & 14.2 & 706 & 2.1 & 39.4 & 1.5 & 170 & 7.6 & 173 & 1.06 & 142.0 & 67 & 4770 \\
\hline 2000-2015 & 2115 & 14,092 & 170 & 15,285 & 1311 & 8664 & 81 & 4289 & 32 & 224 & 24 & 2076 & 144 & 2294 & 5.8 & 989 & 1477 & 49,39 \\
\hline
\end{tabular}

Other includes the combined values of clays (ball, fire, fuller's earth, kaolin), gypsum, helium [crude, grade-A (2011-12)], silver (2013), talc (crude), and zeolites. Data modified and compiled from the U.S. Geological Survey minerals yearbooks [3] 
Fig. 2 Production value trends of major Texas industrial minerals from 2000 through 2015. Other includes the combined values of all clays, dimension stone, gypsum, helium [crude, grade-A (2000-12)], silver (2013), talc, and zeolites. Data modified and compiled from the U.S. Geological Survey, Minerals Yearbook [3]

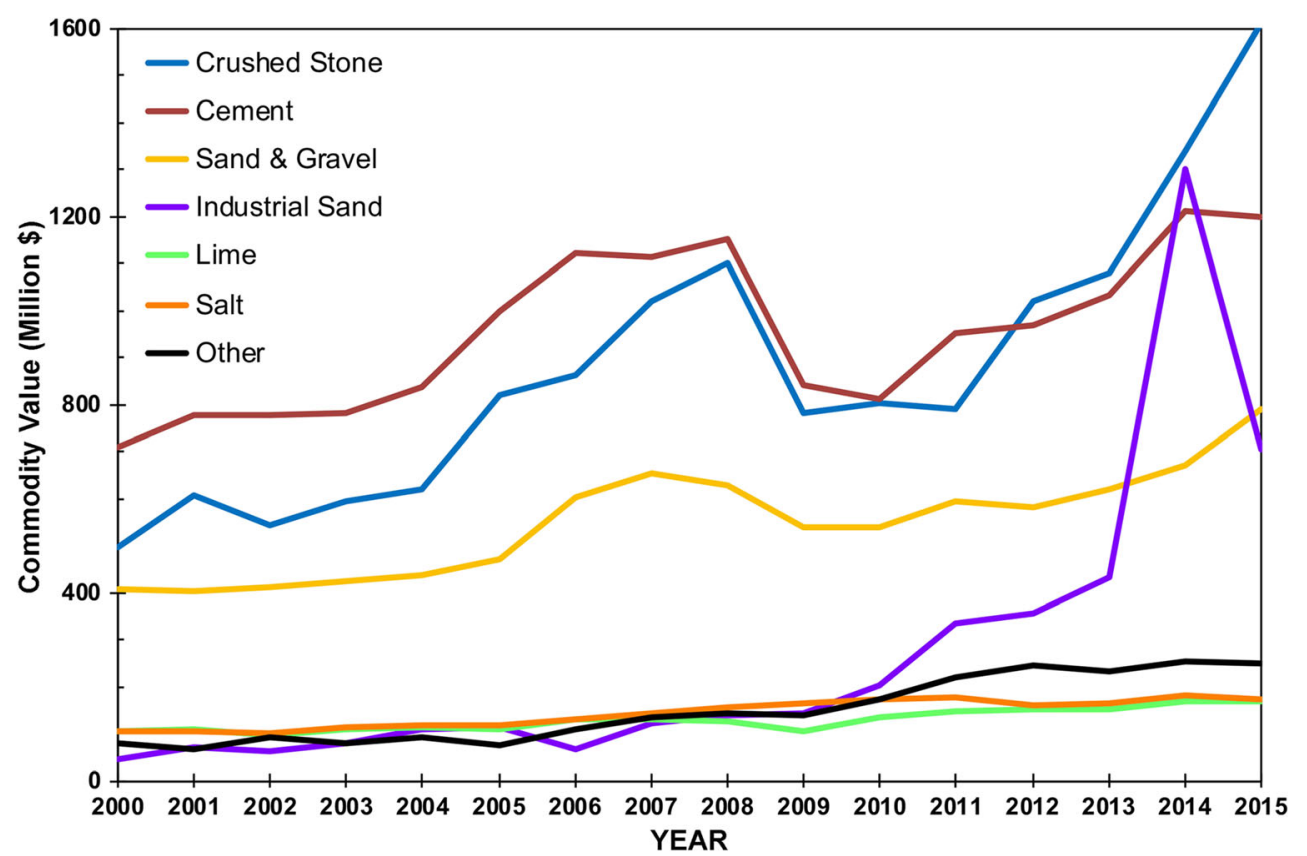

challenges, for mineral resource access. For low unit value industrial minerals, near-coastal markets may facilitate bulk oceanic transport of international raw materials, in competition with regional land sources that require truck or train transport that is more expensive per unit. However, imported industrial minerals may be subject to tariffs.

Industrial mineral consumption is focused in metropolitan areas, of which Texas has 25 with populations greater than 100,000. The five major metropolitan areas-Houston, Dallas-Fort Worth, San Antonio-New Braunfels, AustinRound Rock, and El Paso-total more than 19 million residents (Texas Demographic Center). The four most populous cities, along with several smaller metropolitan regions, occur in the eastern portion of the state. This collective market coupled with favorable surface geology for construction materials dominates the pattern of industrial mineral production in Texas (Fig. 3). Favorable transportation networks, particularly for maritime bulk transport, may result in supply competition from out-of-state or international producers.

Variants on these issues include NIMBY perspectives where rapidly growing population centers may displace or preclude resource development. However, some former industrial mineral production sites have been repurposed as exceptional commercial sites, e.g., Alamo Quarry Market and Six Flags Fiesta Texas in San Antonio.

MSHA lists more than 700 active or intermittently active mining and processing operations in Texas with more than 11,500 employees (Table 2) [4]. In terms of industrial mineral operations, the largest sectors in terms of employment are crushed stone with almost 3000 employees, sand and gravel (including industrial sand) with more than 2300, cement with almost 1500, and dimension stone with greater than 1000 .
Individual operations vary greatly in size from more than 250 employees to fewer than 10 , not only by the scale of the extraction operation, but whether there are corporate and/or downstream components at the production site.

\section{Geologic Framework of Texas Industrial Minerals}

All mineral resources are products of past geologic events, in this case, that have created and modified this portion of Earth's crust over the past 1.5 billion years (Fig. 3) [9, 11, 12]. Collisional plate tectonic processes created a vast Mesoproterozoic orogenic belt, the deeply eroded roots of which form the basement for most of Texas. While covered by younger strata in most of Texas, local exposures of these 1.4- to 1.1-Ga metamorphic rocks and granites are present in the Llano region of central Texas (Fig. 3), as well as smaller areas of west Texas [13]. These igneous and metamorphic rock units are sources of diverse construction and chemical materials, ranging from dimension stone to talc.

Following an extensive period of uplift and erosion that reduced this region to one of low topographic relief, most of Texas was progressively covered by shallow seas starting in the early Paleozoic following the tectonic breakup of the Rodinia supercontinent [12]. Although largely marine in origin, the basal Upper Cambrian Hickory Sandstone includes grains reworked from aeolian deposits that developed during extended Neoproterozoic erosion. The Hickory is overlain by extensive Cambrian-Ordovician limestones and dolostones that formed in shallow seas on the "Great American Carbonate Bank" [14]. 


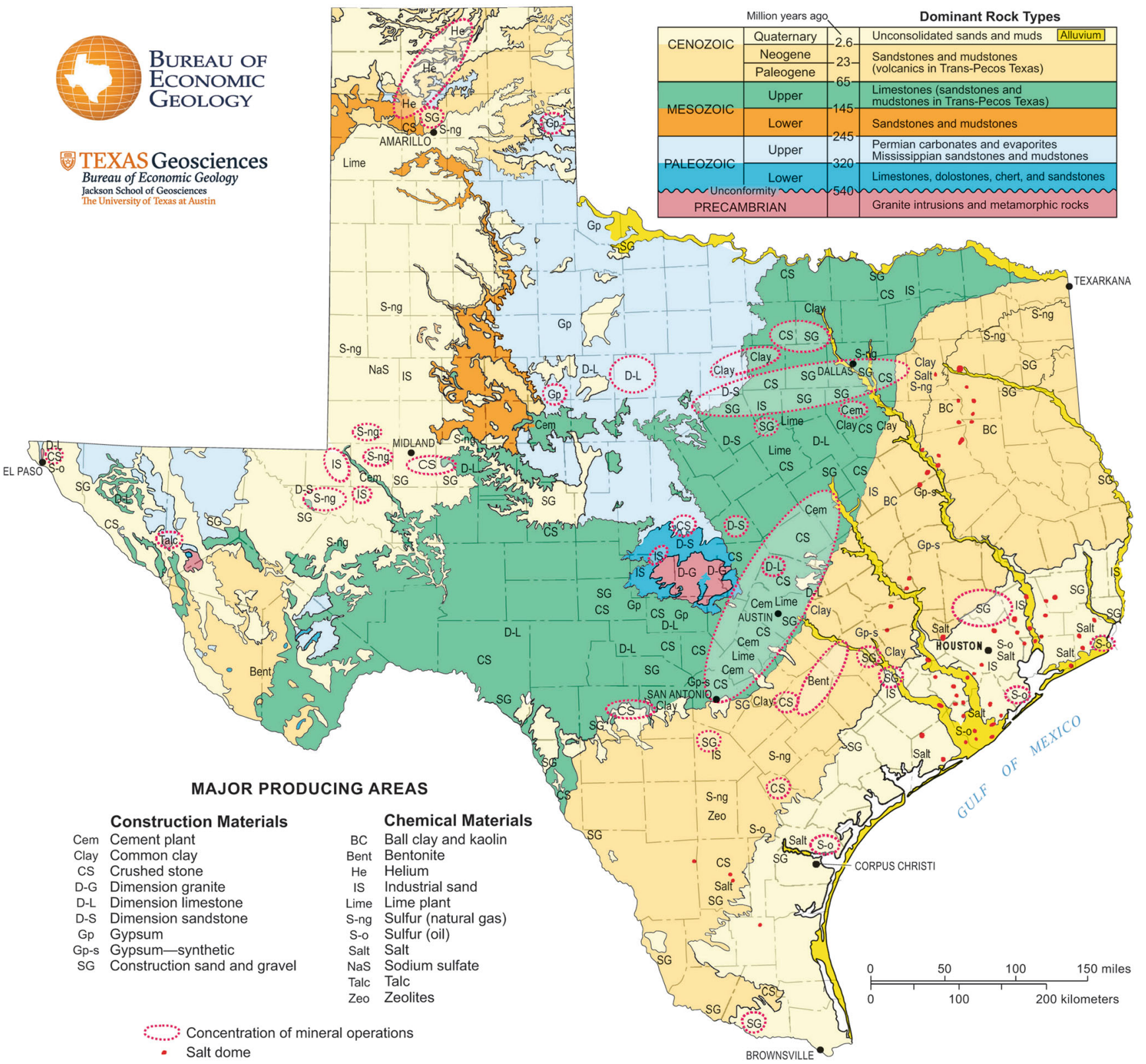

Fig. 3 Generalized geologic map of Texas showing location of major industrial mineral production areas. Modified from [9]

The later Paleozoic records the collision of the North American continent with South America resulting in the Ouachita Orogeny that thrust deeper water strata over equivalent shelf deposits during the formation of this portion of the Pangaea supercontinent [12]. These units are largely covered by Mesozoic and younger strata, with local exposures around the Llano Uplift in central Texas and the Marathon Uplift in west Texas. This collisional event formed the tectonic components of the Permian Basin in west Texas and contiguous regions, including the major petroleum-bearing basins. Late Permian evaporation of shallow seas produced gypsum- and salt-bearing strata, including the potassium-rich salts of the Delaware Basin, forming the major potash deposits in the Carlsbad, New Mexico, area [15].
Following the breakup of Pangaea during the early Mesozoic to initiate the formation of the Gulf of Mexico, ideal evaporitic conditions resulted in the formation of the extensive and thick Jurassic Louann Salt in the rifted margin. The evaporitic strata underlie major portions of the Coastal Plain, extending to and beyond the continental shelf. Salt diapirism began in the Mesozoic and continues to the present [16]. Numerous salt domes with relatively shallow apices occur in the Coastal Plain, making salt available for mine or solution extraction, as well as storage facilities for petroleum and other products (Fig. 3) [17].

With the establishment of normal marine conditions during the Cretaceous, shallow shelf environments produced the extensive carbonate strata that form the Edwards Plateau and 
Table 2 Operational and employment summary for Texas industrial mineral production

\begin{tabular}{lrrrrr}
\hline & Number of operations & Number of counties & \multicolumn{2}{l}{ Number of employees } \\
\cline { 4 - 6 } Commodity & & & Min & Max & Total \\
\hline Cement & 11 & 7 & 72 & 274 & 1474 \\
Crushed stone & 263 & 100 & 1 & 230 & 2980 \\
Dimension stone & 95 & 27 & 1 & 62 & 1045 \\
Sand and gravel & 243 & 97 & 1 & 75 & 2329 \\
Industrial sand & 25 & 19 & 2 & 25 & 199 \\
Common clays & 20 & 13 & 2 & 157 & 447 \\
Specialty clays & 7 & 7 & 1 & 14 & 30 \\
Gypsum & 9 & 6 & 2 & 47 & 114 \\
Lime & 6 & 6 & 15 & 127 & 405 \\
Salt & 2 & 2 & 48 & 215 & 263 \\
Shell & 7 & 4 & 3 & 5 & 27 \\
Talc & 2 & 11 & 14 & 17 & 31 \\
Coal & 14 & & 28 & 312 & 2156 \\
Total & 704 & & & & 11,578 \\
\hline
\end{tabular}

Compiled from [4]. Overall Department of Labor employment data for "mining" shows much higher employee numbers because the sector includes employment in all extractive industries, notably including oil and gas other surface belts that are essential to Texas' crushed stone, cement, and lime production (Fig. 3). Evaporation of the shallow Cretaceous seas also resulted in local gypsum-bearing strata that are largely produced for use in the cement industry.

Cenozoic deposits blanket older geologic units over much of Texas and supply many valuable industrial mineral resources (Fig. 3). Cenozoic strata were deposited by fluvial and coastal processes that distributed gravels, sands, and muds eroded from the ancestral Rocky Mountains and the continental interior. Deposition of these thick sedimentary sequences built the Coastal Plain and extended the Texas shoreline to its current position (and beyond during the most recent glacial period that resulted in lower sea level 18,000 years ago). Coastal Plain Cenozoic strata and unconsolidated alluvial deposits of Texas' major river systems are the source of construction sand and gravel, as well as much of the common clay used in brick and ceramics (Fig. 3). Volcanic ash from mid-Cenozoic eruptions in Trans-Pecos Texas and elsewhere in southwestern North America supplied atypical Coastal Plain sediments that were altered to valuable industrial zeolites, bentonites, and other clay deposits.

Trans-Pecos Texas, arguably the most diverse geologic region of Texas, has been affected by several younger tectonic events. This area includes the easternmost effects of the late Cretaceous Laramide Orogeny that are overprinted by the extensional tectonic regime that remains active [12]. Hydrothermal systems associated with early to midCenozoic magmatic activity produced a variety of hydrothermal mineral deposits, including industrial minerals such as fluorspar with local enrichment of beryllium, uranium, and rare earth elements [18].
The 1.5-billion-year geologic history recorded in Texas geology has endowed the region with diverse industrial rock and mineral resources that are heavily utilized by the population of the region in support of their daily activities.

\section{Texas Construction Materials}

Crushed stone, gravel, and sand that are consumed in large quantities by the construction industry dominate industrial mineral production throughout Texas, from sites commonly near the major metropolitan areas. About $75 \%$ of current Texas industrial mineral value comes from the production of cement, crushed stone, and construction sand and gravel (Fig. 4). Increased production and consumption of these construction materials are tied to regional population increases (Figs. 5 and 6), a trend that is projected to continue [19, 20].

\subsection{Crushed Stone}

Texas produces more crushed stone (162 million tonnes in 2015) than any other state from more than 260 active quarries in 100 counties [4]; more than 700 quarries have been permitted [7]. The production value of crushed stone for 2015 was $\$ 1.6$ billion (Figs. 2 and 4) [1]. Limestone is the most common crushed stone in Texas [22], with production dominated by the Cretaceous limestones that form the surface exposures of the Edwards Plateau in central Texas northward to the Oklahoma border (Figs. 3 and 6). Lesser production comes from Cambrian-Ordovician limestones and dolostones exposed around the Llano Uplift in central Texas and in fault blocks 
near El Paso. Permian limestones are extensive in western Texas and provide local sources of construction materials. Uncommon crushed stone products are sourced from a Cenozoic granitic laccolith at Sierra Blanca in west Texas and from Cretaceous basaltic centers in the Uvalde area of south Texas for railroad bases, pavement coatings, and glass products.

\subsection{Sand and Gravel}

Approximately 240 operations produce sand and gravel in Texas in 97 counties, with most located in the Coastal Plain (Fig. 6) [4, 19]. Most of these operations produce and separate unconsolidated materials that were formed by active or ancient fluvial systems (Fig. 3). Total construction sand and gravel production for 2015 was $83.7 \mathrm{Mt}$. with a value of almost $\$ 790$ million (Table 1; Fig. 4) [3].

\subsection{Cement}

Cement is manufactured from limestone and clay by heating in rotary kilns to produce a synthetic product that is an invaluable material for modern construction [23]. Annual cement production in Texas typically exceeds $\$ 1$ billion (Fig. 2) with a 2015 production of 10.5 million tonnes valued at $\$ 1.2$ billion (Fig. 4) [3]. Because of its immediate and regional use in the construction industry, cement production is a revealing commodity that tracks the strength of local and regional economies. Texas' 11 cement plants in 7 counties are mostly associated with the extensive Cretaceous limestones in central and north Texas (Fig. 3) that are near major consumption centers and transportation networks. Other plants support industrial activities within the Permian Basin of west Texas, with cement imported from contiguous Mexico currently supplying the greater El Paso market.

\subsection{Gypsum}

Gypsum is used in cement manufacture, as well as for plaster and wallboard in building interiors. Texas has nine gypsum mines in six counties (Table 2). Most commercial Texas production is from Permian evaporitic strata of north-central Texas (Fig. 3); extensive Permian gypsum deposits of the Delaware Basin in west Texas are not produced at present. Cretaceous gypsum deposits on the Edwards Plateau are used primarily in the central Texas cement industry. Synthetic gypsum produced from flue gas desulfurization represents an alternative supply for natural gypsum in a variety of uses. However, this supply may be reduced by the closure of some coal-fired electricity-generating plants.
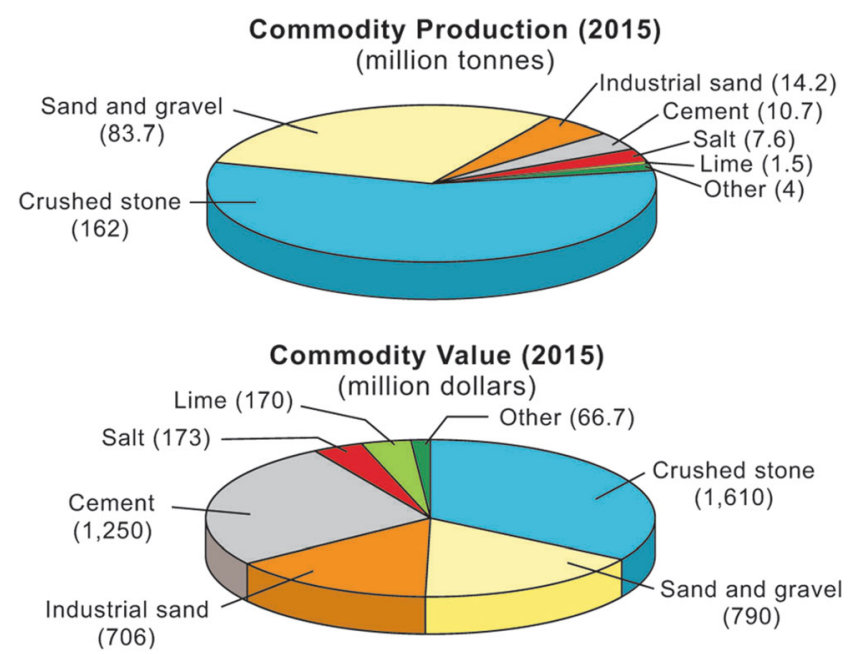

Fig. 4 Tonnage (million t) and value (million \$) of Texas industrial mineral production for 2015. Other includes the combined values of all clays, dimension stone, gypsum, helium (crude), lime, talc, and zeolites. Data modified and compiled from [3]

\subsection{Clays}

Clays of various types largely in the Coastal Plain (Fig. 3) are used in many products, with common clay consumed in large quantities in the manufacture of bricks and tile. Twenty operations in 13 counties produce common clays for the regional construction industry (Table 2) [4].

\subsection{Dimension Stone}

Several geologic types of dimension stone, mostly for monuments and building exteriors but with growing high-end residential use, are produced in Texas [24]. Approximately 100 operations in 27 counties currently produce dimension stone (Table 2) [4]. Although relatively small compared to other construction materials, the tonnage and value of Texas' dimension stone production has had more than an order of magnitude increase in the last decade to a $\$ 150$ million industry (Table 1). Cretaceous grainstone and fossil-moldic limestones are popular local architectural dimension stones, with lesser use of grainstones and sandstones of other geologic ages. The Mesoproterozoic granites of the Llano Uplift in central Texas (Fig. 3) were used to build the Texas state capitol and numerous other state and county government buildings and continue to be in demand for dimension stone and other purposes.

\subsection{Industrial Sand}

Large amounts of sand are produced for construction purposes, e.g., masonry sand, but specialized industrial sand products have seen a great increase in demand over the past decade. The Texas industrial sand production value of $\$ 1.3$ billion in 2014 exceeded that of cement and was almost as 
Fig. 5 Texas population growth by counties for 2015 showing the largest increases in counties adjacent to major metropolitan areas $[19,20]$

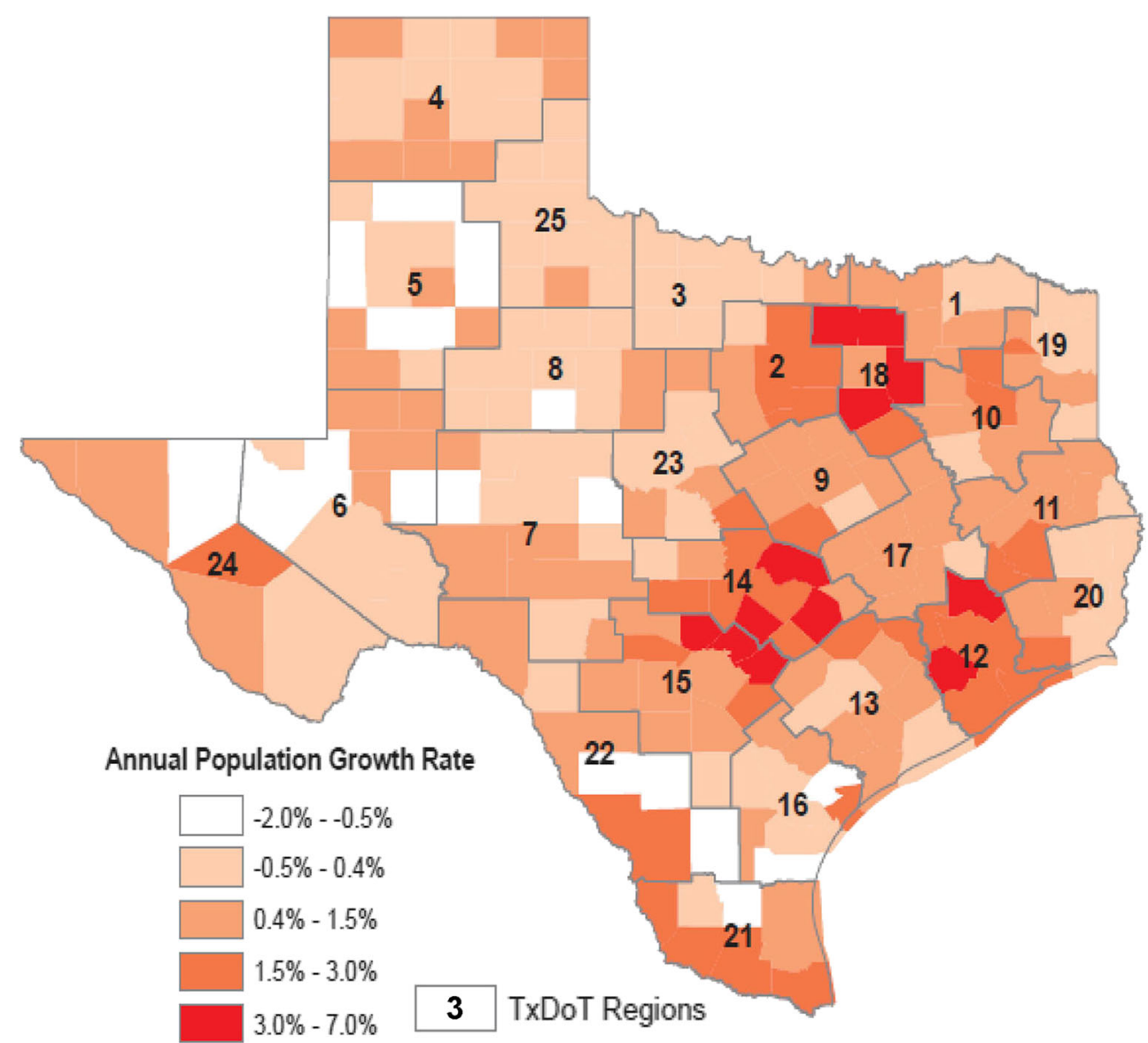

much as the value of crushed stone (Fig. 2; Table 1). A timely example of how developments in one industry may have interrelated effects in another is the recent growth in production of petroleum from "unconventional" reservoirs. Although directional drilling and hydraulic fracturing techniques have been used for decades, a major increase in these operations was required for hydrocarbon production from unconventional shale reservoirs. Texas has multiple unconventional petroleum plays, and in-state production of industrial sands for proppants has doubled in the past decade.

One of Texas' major industrial sand areas is the northwestern margin of the Llano Uplift in central Texas where sands are produced from the upper Cambrian Hickory Sandstone. Despite its great age, the Hickory remains friable in this area because it was never buried deeply along the flanks of the Llano Uplift. Because of its poorly cemented nature and the occurrence of well-rounded quartz grains in a variety of sizes appropriate for various proppant applications [25, 26]. This area has been a source of industrial sand for several decades [27], but production has steadily increased in the past decade supplying the unconventional petroleum plays in north Texas and in the Permian Basin. Production generally is from a nearsurface 15 - to $20-\mathrm{m}$ (50- to 65-ft) interval in the lower Hickory [25], and a considerable resource remains [26].
Additional industrial sand operations have been developed for proppant production in the unconsolidated Cenozoic deposits of east and south Texas Coastal Plain (Fig. 3). A total of 19 counties have industrial sand operations (Table 2), and that number is expanding. With transportation costs being a key economic factor for many industrial mineral operations, operators have recently started to develop proppant sand supplies from surficial aeolian deposits (Fig. 7) in the southern High Plains [28] for Permian Basin hydraulic fracturing operations. Currently, more than 25 properties have been permitted with production ramping up to support expanding Permian Basin unconventional hydrocarbon production (Fig. 7).

Development of these "in-basin" sands represents a shift in the natural sand proppant industry, moving to locally sourced sands and away from premium sand resources that require long-distance transport. Several factors have contributed to this trend, including an increase in active rigs, increase in wells per rig, increasing lateral length of horizontal drilling, and increase in proppant use per lateral increment, and a shift in proppant size from coarse to finer sand fractions that demonstrate higher resistance to stress in the production of deeper oil and gas formations. More than $80 \%$ of US hydraulic fracturing sand consumption is 40/70, 100 and finer mesh sand product, an increase of more than $60 \%$ since 2014 . More than 
Fig. 6 Texas construction material quarries for crushed stone and sand and gravel $[19,21]$

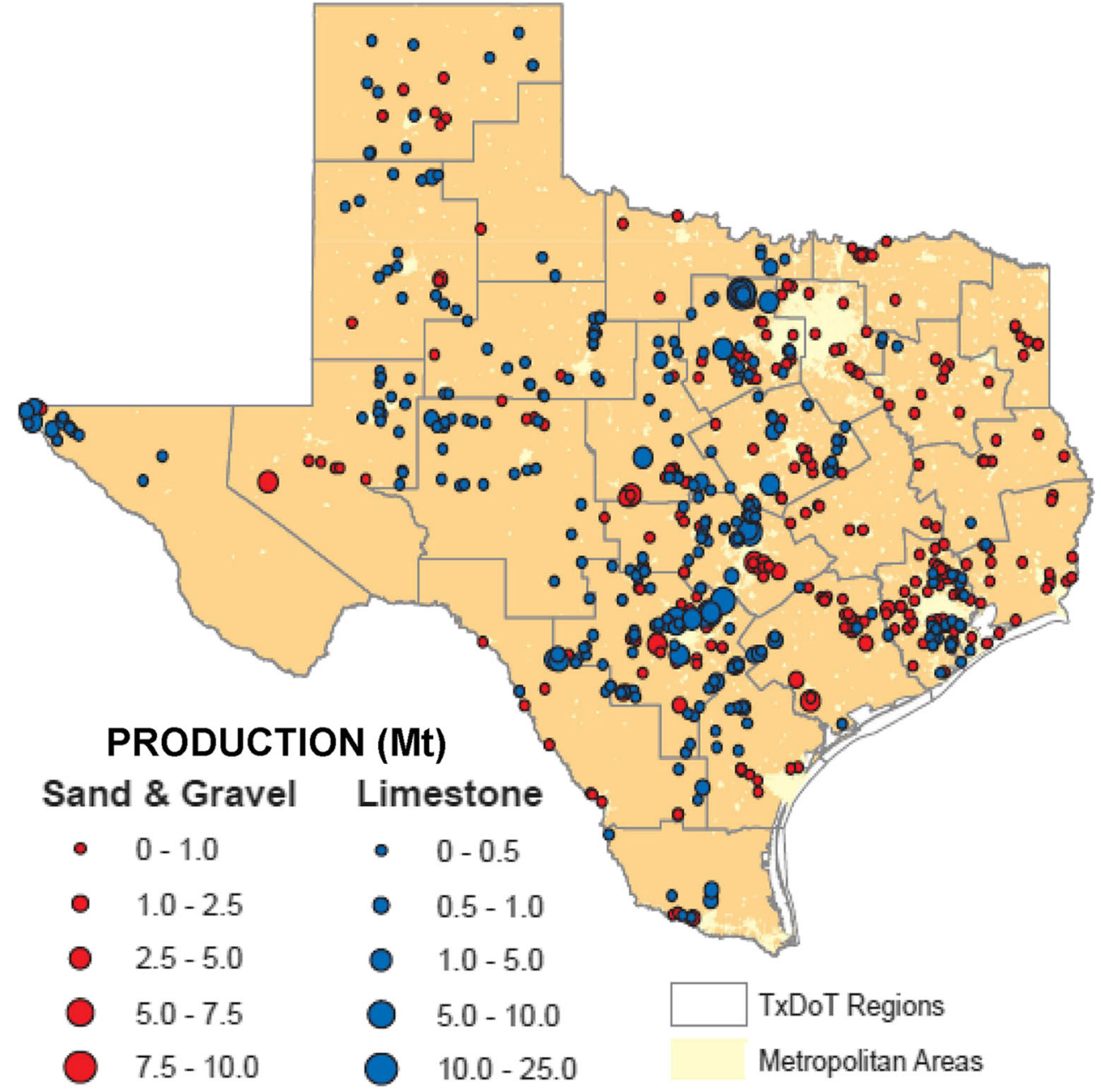

$85 \%$ of the sand used in Permian Basin hydraulic fracturing is 40/70 mesh and finer. The critical factors of roundness, sphericity, and crush strength for finer mesh sizes have been reported to be similar to premium sand and suitable for production engineers to replace more expensive proppant sources. The abundant local sand resources with low transportation cost are expected to supply much of the proppant demand for the increased petroleum-drilling activity in the Permian Basin.

\section{Texas Chemical Minerals}

Many industrial minerals are used in the chemical industries, from primary industrial applications to secondary applications in which they serve as sources of valuable elements.

\subsection{Salt}

Salt (sodium chloride) has diverse uses, but most is produced as a chlorine source for the manufacture of hydrochloric acid, a widely used industrial chemical. Salt is produced in the
Coastal Plain region from seven brine operations and from mines in two salt domes (Fig. 3), supplying a total of 7.6 million tonnes with a value of $\$ 173$ million (Table 1) [3]. Caverns excavated within salt domes provide inert and sealed containers for the storage of diverse products, with such facilities in 19 domes in Texas with more than 300 active caverns [17]. These caverns serve as storage for crude oil, liquified petroleum gas, and natural gas. The US Strategic Petroleum Reserve is hosted in 62 caverns in four Texas and Louisiana salt domes and currently has a storage capacity of more than 700 million barrels of crude oil [30].

\subsection{Lime}

Lime (calcium oxide produced by calcining limestone) has many uses, including water purification, paper manufacture, and sugar refining. Lime is produced from five operations in five central Texas counties utilizing Cretaceous limestones [4]. The production value for 2015 was $\$ 170$ million [3]. Limestone also has many other chemical uses, including flue gas desulfurization of $\mathrm{SO}_{2}$ from coal-fired electricity-generation plants to produce synthetic gypsum. 


\subsection{Sulfur}

Sulfur is an important industrial chemical that is used principally for the manufacture of sulfuric acid which is used extensively in the production of chemical fertilizers. Sulfur was once produced in large quantities from native sulfur deposits of microbial origin in Coastal Plain salt-dome cap rocks and in altered Permian evaporite strata in the Delaware Basin of west Texas $[17,31]$. These deposits were extracted via the Frasch process, involving the injection of superheated water into the sulfur-bearing formation to liquefy the sulfur to allow it to be pumped to the surface. Although identified resources of these types of sulfur deposits remain, these sulfur concentrations ceased to be economically viable with the expansion of nondiscretionary sulfur production related to the Clean Air Act. The last Texas production was from the Culberson deposit in west Texas in 1999. Now, sulfur is produced in more than 60 refineries of "sour" crude oil and natural gas from domestic and international sources. Although no longer tallied under state industrial mineral production, Texas remains the leading US sulfur-producing state, with 3.2 million tonnes in 2015 accounting for $\sim 37 \%$ of US production [3].

\subsection{Specialty Industrial Minerals}

Specialty clays, zeolites, helium, sodium sulfate, and talc are additional chemical materials currently produced in Texas (Fig. 2). Although most of Texas clay production is common clay for the manufacture of bricks and other building materials, seven operations produce specialty clays for a variety of purposes (Table 1). Bentonitic clays are produced in the central Gulf Coast (Fig. 3) for diverse uses in industrial processes including drilling fluids and refining of vegetable oils. Ball and kaolin clays are used as fillers and coating agents in the rubber and paper industry and in ceramic products. A single mine in the south-central Gulf Coast produces zeolites developed in mid-Cenozoic volcanic ash (Fig. 3). Their zeolites are marketed for their ion-exchange capacity, as used in water treatment and other purification processes. Additional clay- and zeolite-bearing strata occur in the region and could be developed with increased demand and favorable economic scenarios.

The principal domestic source of helium is from natural gas in the Hugoton and other fields in the Panhandle of Texas and
Fig. 7 Surface geology of the southern High Plains of Texas showing surficial sand deposits [29] that are being developed for "in-basin" supplies of proppants for Permian Basin unconventional petroleum production

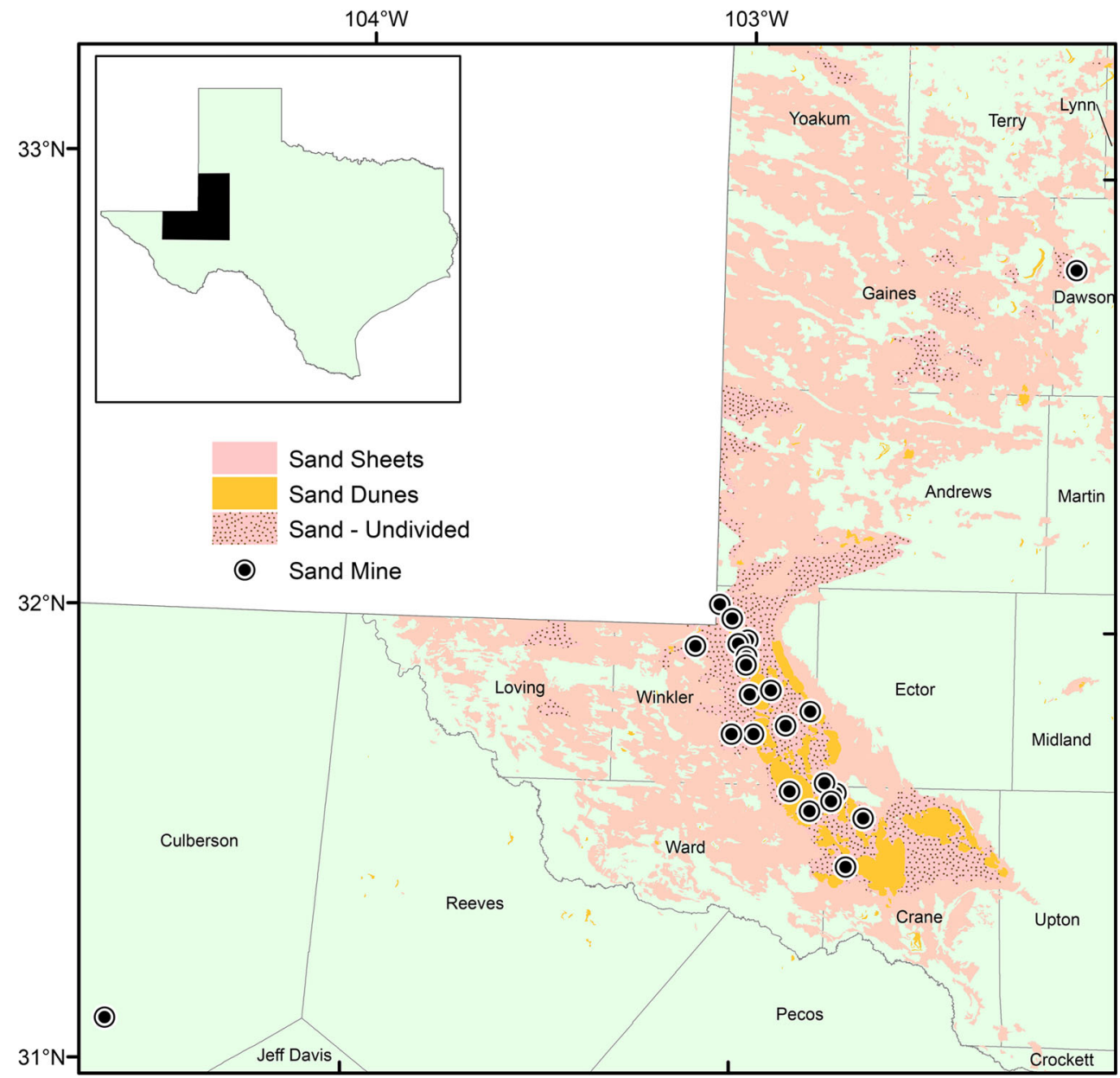


adjacent states (Fig. 3). The National Helium Reserve is stored in a depleted natural gas reservoir near Amarillo [3].

Sodium sulfate is produced from brines pumped from the subsurface underlying a former alkaline lake in western Texas (Fig. 3). The interstitial brine well field produces from a depth of 25 to $30 \mathrm{~m}$ ( 80 to $100 \mathrm{ft}$ ).

Talc is used for fillers in ceramics, paper, plastic, and rubber products. Talc deposits of the Allamoore district occur in Mesoproterozoic carbonate strata near Van Horn in west Texas and are associated with complex tectonic and fluid events along the 1.0 billion-year-old Streeruwitz thrust [32]. Both paint- and ceramic-grade talc is produced.

The demand for rare earth elements, a diverse group of metals used in a variety of technology applications from wind turbines to guidance systems, has increased recently with REE prices majorly affected by restrictions in the international supply of the refined metals. The Paleogene Round Top laccolith in western Texas has been evaluated for its rare earth element potential, as well as localized concentrations of beryllium and uranium $[18,33,34]$. Other similar shallow igneous intrusions remain to be evaluated.

\section{Discussion and Conclusions}

Texas' abundant and varied industrial mineral resources are products of a geologic history affecting this part of the Earth's crust for more than a billion years. The use of Texas' industrial mineral resources began in Prehistory and continues at an accelerated rate today tied to societal and technology changes.
The total value of Texas' industrial mineral production for 2017 was more than $\$ 5$ billion [1], with additional value supplied by energy mineral production and unrecorded nondiscretionary industrial mineral production, e.g., recovered sulfur. Industrial rocks and minerals are produced in virtually every Texas county, commonly related to local transportation, construction, and other industrial activities. Industrial mineral production provides local employment, and unusual mineral concentrations provide specialty products for regional distribution. As Texas' population continues to grow, in-state production of industrial minerals will continue to satisfy the demands of residential, commercial, and industrial customers (Fig. 8).

Increased production and consumption of industrial mineral resources is tied to regional population increases, a trend that seems likely to continue with the state's population projected to reach as high as 50 million by 2050 (Fig. 8) [35]. Texas provides a notable case study for the forecast that $60 \%$ of the urban infrastructure required in 2050 is yet to be built [36]. Current rising sea levels will also require infrastructure adjustments. This new infrastructure will require huge amounts of construction and other mineral resources. Successful exploration for and development of new industrial mineral production sites will be guided by near-surface geologic occurrences, balanced against competing land uses, environmental considerations, and available transportation networks. Near-coastal major consumption sites may result in an increased supply of bulk industrial raw materials via oceanic transport from international sources, in competition with regional land sources and transport. Developments in other
Fig. 8 Projected Texas population growth and industrial mineral valuation to 2050 . Population data and projections from [37]

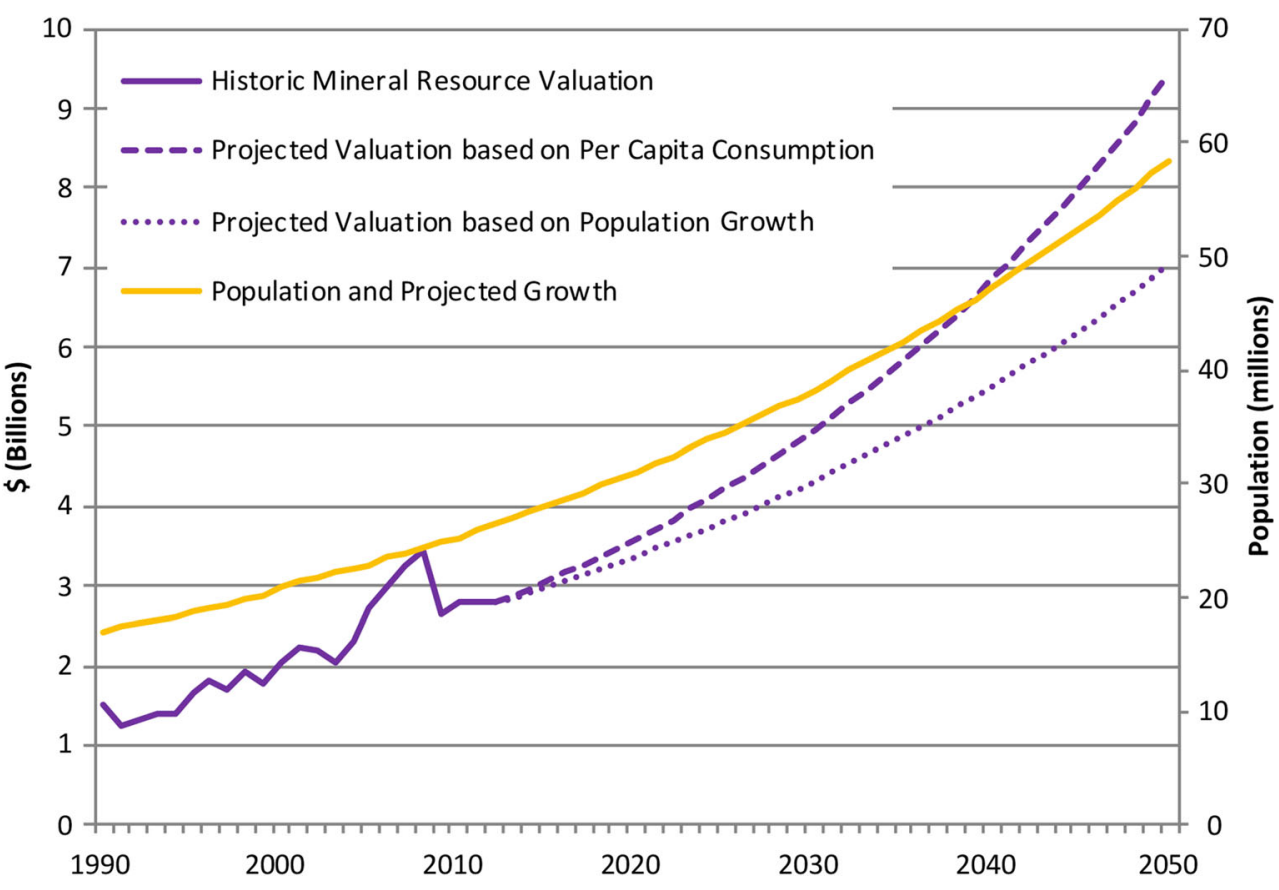


resource industries, as well as governmental regulation, can have major impacts on industrial mineral production and consumption issues. Understanding the geologic and economic framework of the Earth resources allows for more informed decisions about the societal issues that Texas and other regions will face in the future.

Acknowledgments This study was greatly enhanced by regional mapping products produced by the Bureau of Economic Geology, and funded through the United States Geological Survey Mapping Cooperative Program, STATEMAP Award No. G14AC0020. We are grateful to many landowners and mining companies that have allowed access to their properties for educational and research purposes. We thank the U.S. Geological Survey National Minerals Information Center for providing an early copy of the USGS 2014-15 compilation of Texas industrial mineral production data. We appreciate the insightful review of the manuscript by Virginia McLemore, Robert Callaghan, and three anonymous reviewers that improved the final presentation.

Funding Information Funding for this study was provided by the State of Texas Advanced Resource Recovery program through the University of Texas at Austin, Bureau of Economic Geology, Mineral Resource Program.

\section{Compliance with Ethical Standards}

Conflict of Interest The authors declare that they have no conflict of interest.

Open Access This article is distributed under the terms of the Creative Commons Attribution 4.0 International License (http:// creativecommons.org/licenses/by/4.0/), which permits unrestricted use, distribution, and reproduction in any medium, provided you give appropriate credit to the original author(s) and the source, provide a link to the Creative Commons license, and indicate if changes were made.

Publisher's Note Springer Nature remains neutral with regard to jurisdictional claims in published maps and institutional affiliations.

\section{References}

1. Staff, U.S. Geological Survey, National Minerals Information Center (2018) Mining Review. Annual Review 2017. Min Eng 69(5):51-60

2. Texas Population Estimates and Projections Program, Texas Demographic Center, Univ of Texas at San Antonio, http://xsdc. utsa.edu. Accessed 27 Apr 2018

3. Texas State Minerals Information, U.S. Geological Survey http:// minerals.usgs.gov/minerals/pubs/state/tx.html. Accessed 23 Sept 2018

4. Mine Safety and Health Administration-MSHA (2017) Mines data set. Department of Labor, U.S. https://arlweb.msha.gov/ OpenGovernmentData/OGIMSHA.asp\#msha-datasets. Accessed 25 Jul 2017

5. Economic Mineral Resources Program, Bureau of Economic Geology, Univ of Texas at Austin, http://www.beg.utexas.edu/ minerals. Accessed 20 Apr 2018
6. Elliott BA (2015) Texas mineral resources map (interactive). Bureau of Economic Geology, Univ of Texas at Austin https:// coastal.beg.utexas.edu/txmineralresources/. Accessed 20 Apr 2018

7. Mining and Mineral Extraction, Texas Commission on Environmental Quality https:/www.tceq.texas.gov/permitting/ mining.html. Accessed 20 Apr 2018

8. Kogel JE, Trivedi NC, Barker JM, Krukowski ST (2006) Industrial minerals \& rocks: commodities, markets, and uses, 7 th edn. Society for Mining, Metallurgy, and Exploration, Englewood $1548 \mathrm{p}$

9. Kyle JR (2018) Industrial minerals of Texas. Bureau of Economic Geology, Univ of Texas at Austin. State Map Ser. SM0011

10. Texas Land Trends (2014) Fact sheet. Institute of Renewable Natural Resources, Texas A \& M Univ http://texaslandtrends.org/ 1t-2014-fact-sheet.pdf. Accessed 4 Sept 2018

11. Kyle JR (2011) Geology of Texas industrial minerals. Austin Geol Soc Bull 7:29-43

12. Ewing TE (2016) Texas through time: Lone Star geology, landscapes, and resources. Bureau of Economic Geology. Univ of Texas at Austin. Udden Series No. 6, $431 \mathrm{p}$

13. Mosher S (1998) Tectonic evolution of the southern Laurentian Grenville orogenic belt. Geol Soc Am Bull 110:1357-1375

14. Gregg JM, Shelton KL (2012) Mississippi Valley-type mineralization and ore deposits in the Cambrian - Ordovician Great American Carbonate Bank. In: Derby JR et al (eds) The Great American Carbonate Bank: the geology and economic resources of the Cambrian - Ordovician Sauk megasequence of Laurentia, AAPG Memoir, vol 98, pp 161-185

15. McLemore VT (2017) Update on industrial minerals and rocks of New Mexico. Min Eng 69(6):49-56. https://doi.org/10.19150/me. 7566

16. Hudec MR, Jackson MPA (2007) Terra infirma: understanding salt tectonics. Earth-Sci Rev 82:1-28

17. Kyle JR (1999) Industrial mineral resources associated with salt domes, Gulf of Mexico basin, U.S.A. In: Johnson KS (ed) Proceedings, 34th forum on the geology of industrial minerals, Oklahoma Geological Survey. Circ, vol 102, pp 161-178

18. O’Neill LC, Elliott BE, Kyle JR (2017) Mineralogy and crystallization history of a highly differentiated REE-enriched hypabyssal rhyolite: Round Top laccolith, Trans-Pecos, Texas. Mineral Petrol 111:569-592. https://doi.org/10.1007/s00710-017-0511-5

19. Verma R, Siddiqui MS, Alqarni A, Elliott BA, Whitney D, Fowler DW (2015) Present and future aggregate resources analysis. Unpubl. contract report, Texas Department of Transportation, Center for Transportation Research, University of Texas at Austin, $75 \mathrm{p}$

20. Texas Workforce Commission http://www.twc.state.tx.us. Accessed 1 Nov 2015

21. Texas Department of Transportation https://www.txdot.gov. Accessed 1 Nov 2015

22. Garner LE (1994) Limestone resources of Texas. Bureau of Economic Geology, Univ of Texas at Austin. MRC 84, $16 \mathrm{p}$

23. McBride MW, Patty TS, Sharpe RD (1992) Texas Portland cement industry and cement resources. Bureau of Economic Geology, Univ of Texas at Austin. MRC 83, $72 \mathrm{p}$

24. Garner LE (1992) The dimension stone industry of Texas. Bureau of Economic Geology, Univ of Texas at Austin. MRC 82, 16 p

25. Kyle JR, McBride EF (2014) Geology of the Voca frac sand district, western Llano Uplift, Texas. In: Conway FM (ed) Proceedings, 48th annual forum on the geology of industrial minerals, Arizona Geological Survey special paper 9, ch 2, pp 1-13. http://repository. azgs.az.gov/uri_gin/azgs/dlio/1563. Accessed 10 Feb 2014

26. Elliott BA, Verma R, Kyle JR (2016) Prospectivity modeling for Cambrian-Ordovician hydraulic fracturing sand resources around the Llano Uplift, central Texas. Nat Resour Res 25:389-415. https://doi.org/10.1007/s11053-016-9291-6 
27. Barnes VE, Schofield DA (1964) Potential low-grade iron ore and hydraulic-fracturing sand in Cambrian sandstones, northwestern Llano region, Texas. Bureau of Economic Geology, Univ of Texas at Austin. RI 53, $58 \mathrm{p}$

28. Holliday VT (2001) Stratigraphy and geochronology of upper Quaternary eolian sand on the Southern High Plains of Texas and New Mexico, United States. Geol Soc Am Bull 113:88-108. https://doi.org/10.1130/0016-7606(2001)113<0088:SAGOUQ >2. $0 . \mathrm{CO} ; 2$

29. Estepp J (2004) Digital GIS Quadrangles - Texas. Derived from the geologic atlas of Texas $(1: 250,000)$, Barnes, VE, project coordinator, Bureau of Economic Geology, Univ of Texas at Austin https:// www.twdb.texas.gov/groundwater/aquifer/GAT/. Accessed 7 Sept 2018

30. Strategic Petroleum Reserve, U. S. Department of Energy https:// energy.gov/fe/services/petroleum-reserves/strategic-petroleumreserve. Accessed 4 Sept 2018

31. Kyle JR (2002) A century of fire and brimstone: the rise and fall of the Frasch sulphur industry of the Gulf of Mexico basin. In: Scott PW, Bristow CM (eds) Industrial minerals and extractive industry geology. Geological Society London, Spec Publ, London, pp 189198
32. Davis BR, Mosher S (2015) Complex structural and fluid flow evolution along the Grenville Front, west Texas. Geosphere 11: 868-898. https://doi.org/10.1130/GES01098.1

33. Pingitore NE Jr, Clague JW, Gorski D (2018) Remarkably consistent rare earth element grades at Round Top yttrofluorite deposit. Adv Mater Phys Chem 8:1-14. https://doi.org/10.4236/ampc.2018. 81001

34. Rubin JN, Price JG, Henry CD, Koppenaal DW (1987) Cryolitebearing and rare metal-enriched rhyolite, Sierra Blanca Peaks, Hudspeth County, Texas. Am Mineral 72:1122-1130

35. Potter L, Hoque N (2014) Projections of the population of Texas and counties in Texas by age, sex, and race/ethnicity for 2010 2050. Texas State Data Center, University of Texas at San Antonio http://demographics.texas.gov/Resources/Publications/ 2014/2014-11_ProjectionBrief.pdf. Accessed 27 April 2018

36. Olivetti EA, Cullen JM (2018) Toward a sustainable materials system. Sci 360(6396):1396-1398. https://doi.org/10.1126/science. aat6821

37. Texas Department of State Health Services https://www.dshs.texas. gov/chs/popdat/downloads.shtm. Accessed 20 April 2018 